\title{
УКЛОНЕНИЕ ОТ УПЛАТЫ НАЛОГОВ ПОСРЕДСТВОМ ОФФШОРНЫХ СХЕМ: НЕКОТОРЫЕ ТЕОРЕТИКО-ПРИКЛАДНЫЕ АСПЕКТЫ
}

Аннотация: Предметом исследования являются преступные способы уклонения от уплаты налогов с использованием оффшорных схем. Объектом исследования являются общественные отношения в сфере уголовно-правовой борьбы с налоговыми преступлениями. Автор подробно описывает механизм оффиорных схем в системе способов преступной неуплаты налогов. Исследуется зарубежный опыт уклонения от уплаты налогов посредством оффшорных схем и способы противодействия данным деяниям. Особое внимание уделяется практическим мерам по борьбе с уклонением от уплаты налогов с использованием оффиорных схем. Исследование основано на диалектическом методе научного познания. Также используется сравнительно-правовой и системно-логический методы. Основными выводами проведенного исследования является то, что автор не только проанализировал возможные преступные способы уклонения от уплаты налогов с использованием оффиорных схем, действуюшие меры в части противодействия такого рода деяниям, но и предложил практические меры по борьбе с данным явлением. Ключевые слова: Налоги, уклонение, способ совершения преступления, оффиор, преступление, наказание, квалификация, уголовный закон, налоговое преступление, бизнес.

Abstract: The subject of this research consists in the illegal ways of avoiding taxation by using the offshore schemes. The object of this research is the social relations in the area of criminal legal fight against tax crimes. The author provides a detailed description of the mechanisms of the offshore schemes within the system of methods to illegally avoid paying taxes. A research is conducted on the foreign experience on tax avoidance by use of the offshore schemes and the way to counter such activity. A special attention is given to the practical measures on the fight against tax avoidance. The research is based on the dialectic method, and uses other methods such as comparative-legal ans systemic-logical. Among the main conclusions of the conducted research is the fact that the author not only analyzed the possible illegal ways of avoiding taxation by using the offshore schemes and the current measures of countering such activities, but also proposed practical measures to counteract this phenomenon.

Keywords: Criminal law, qualification, punishment, crime, offshore, way of committing a crime, evasion, Taxes, tax crime, business.

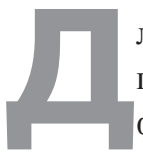

ля современной России, одним из способов преступной неуплаты налогов является вывод финансовых активов из страны регистрации в страны зарубежья, где таковые организации становятся либо фактическими, либо номинальными нерезидентами (возможна, также, регистрация и использование юридически зависимой организации). Таким образом, при выводе активов из Российской Федерации фактически происходит обнищание бюджета страны. Более того, в настоящее время российский рынок финансовых услуг «пестрит» предложениями о переводе бизнеса в оффшор (иногда используется термин - оффшор).

С большой долей вероятности можно предположить, что указанный бизнес создается и управляется группами юридически и экономически образованных лиц, где главная цель - это преступная неуплата налогов в особо крупных размерах с использованием «оффшора».

Необходимо отметить, что государственная политика сегодня ориентирована на противодействие оффшорным схемам неуплата налогов, однако данное направление требует более оперативного вмешательства. Президент Российской Федерации В.В. Путин в ежегодном послании Федеральному Собранию Российской Федерации 12 декабря 2013 года вновь указал на необходимость работы по деофшоризации бизнеса.

Стоит отметить, что в настоящее время в российском законодательстве нет юридического закрепленного по- 


\section{Системы стабилизации: финансовый контроль}

нятия - оффшор. Кроме того, судебная практика относительно уклонения от уплаты налогов с использованием преступных оффшорных схем практически отсутствует.

Нами был проведен анализ судебной практики по Уральскому, Центральному и Южному федеральным округам по фактам преступного уклонения от уплаты налогов с использованием оффшорных схем за период времени 2008-2013 гг., а равно по Тюменской области за период 2004-2013 гг. Исследование показало, что за указанный период в названных регионах не было вынесено ни одного постановления о возбуждении уголовного дела по факту уклонения, сокрытия налогов и, соответственно, не было ни одного приговора суда по указанным видам преступлений, где способообразующим механизмом совершения налогового преступления выступали бы криминальные оффшорные схемы.

Имеется лишь «громкое» исключение из правил - это обвинительный приговор, вынесенный по делу «ЮКОСа» [1]. Из содержания приговора суда по данному делу следует, что по указанию М.Б. Ходорковского и П.Л. Лебедева в зонах со льготным налогообложением на территории России, а так же в оффшорных зонах за рубежом были зарегистрированы многочисленные и периодически меняющиеся компании - посредники. Деятельность всех этих специально образованных фирм носила подставной характер, а их предназначение заключалось в том, чтобы через оформление сделок по движению нефти, нефтепродуктов, ценных бумаг, денежных средств, а с 2000 года также через оформление торгов с заранее известным результатом, легализовать присвоенное имущество нефтедобывающих предприятий. Использование данных схем, также позволяло организованной группе оплачивать минимальные налоги государству. Сотрудникам указанных структур давались рекомендации о том, как юридически правильно обосновать сделки, чтобы под видом гражданско-правовых отношений можно было скрыть их фактическую направленность на легализацию противоправно добытых средств. Таким образом, с момента извлечения нефти из скважины право собственности на нее в соответствии с генеральными соглашениями и договорами купли-продажи вначале переходило к подконтрольным осужденным организациям (в 1998-1999 г. - к ОАО НК «ЮКОС», в 2000-2003 г. - к ЗАО «ЮКОС М», в 20002003 г. - к ЗАО «ЮКОС М», и др.), выполняющим в таких случаях подставные посреднические функции.

Как представляется, для успешного противодействия криминальным оффшорным бизнес-схемам необходим юридически закрепленный понятийный аппарат (прежде всего - «оффшорная зона»).
«Оффшорная зона», по мнению С.А. Молчанова, это независимое государство или территория другого государства (например, колония) с некоторой степенью автономии, законодательство которой предоставляет юридическому лицу значительные налоговые льготы. Такие льготы чаще всего заключаются в полном отсутствии налогообложения при выполнении определенных условий. В оффшорных зонах взимается до 5\% от чистой прибыли, то есть очень низкий налог в сравнении с РФ или Европой, где налог на прибыль составляет в основном 25-30\% [2, с. 426].

Министерство финансов Российской Федерации [3] и Налоговый кодекс Российской Федерации (далее-НК РФ) (п. 1 абз. 3 ст. 284) предлагает следующую трактовку «оффшорной зоны» - это перечень государств и территорий, предоставляющих льготный режим налогообложения и (или) не предусматривающих раскрытия и предоставления информации при проведении финансовых операций.

Что же представляет из себя «оффшорная зона» с практической точки зрения? Так, к примеру, страна регистрации взимает плату за регистрацию и фиктивную ежегодную пошлину (как правило, небольшую). Основной целью создания оффшорной организации обычно является структуризация бизнеса для сокращения налогового бремени основной компании: суммарные расходы по поддержанию оффшорной компании во много раз меньше, чем суммы, которые они экономят на налогах. Простейший вариант использования оффшорной компании в торговых операциях, когда через нее совершаются сделки по импорту или экспорту. Регулируется контрактная цена, владелец компании тем самым регулирует и сумму уплачиваемых налогов и пошлин. Этот механизм называется трансферным ценообразованием: перепродажа товара по разным ценам, используя так называемую «фирму-прокладку», созданную для минимизации налогообложения. Снижение налога на прибыль, в итоге, возможно примерно в 8 (!) раз.

Может, однако, возникнуть вопрос об использовании двойного налогообложения. Но данное требование более чем вероятно будет незаконным, в силу того, что фактическая уплата налога дважды будет незаконна. Примером может являться Кипр (который ранее официально являлся «оффшорной зоной»), с которым было принято Соглашение между Правительством РФ и Правительством Республики Кипр от 05.12.1998 г. (с изм. от 07.10.2010 г.) «Об избежание двойного налогообложения в отношении налогов на доходы и капитал» [3]. 
DOI: $10.7256 / 1811-9018.2015 .3 .14452$

При цитировании этой статьи сноска на доі обязательна

\section{Право и политика $3(183) \cdot 2015$}

Существует множество способов по неуплате налогов в бюджет России с использованием оффшоров: использование выплат связанных с выплатой дивидендов; использование при владении патентным правом, когда все платежи от использования патентного права поступают в зарубежную фирму, зарегистрированную в «оффшорной зоне»; займовая схема при выдаче кредитов связанным между собой компаниям и получение процентов с займом обратно.

Оффшорные компании могут так же использоваться для хранения личных сбережений граждан. Однако, как представляется, в связи с нестабильной ситуацией в мировой политической и экономической структуре, определенные проблемы могут возникнуть и в самих оффшорных зонах. Так 16 марта 2013 года на Кипре властями был введен единовременный налог на банковские вклады (в том числе и на вклады российских резидентов). В итоге, со всех банковских вкладов с суммой менее 100000 евро списано 6,75\%, а с депозитов больше указанной планки - 9,9\%. Так же на Кипре стране в настоящее время повышен и корпоративный налог с оффшоров до $12,5 \%$. Таким образом, можно констатировать, что Правительство Кипра, не взирая не подписанный договор с Россией о недопустимости двойного налогообложения, своевольно изъяло денежную массу из вкладов российских налогоплательщиков.

Министерством финансов РФ ведется мониторинг государств и территорий, предоставляющих льготный налоговый режим налогообложения и (или) не предусматривающих раскрытия и предоставления информации при проведении финансовых операций (оффшорные зоны). Согласно приказу от 13 ноября 2007 года № 108-н Министерства Финансов РФ данный перечень оффшорных зон утвержден и периодически изменяется. Тот же Кипр с 1 января 2013 года был исключен из данного перечня в связи с экономическими преобразованиями в стране. Одним из условий этого послужило согласие Правительства Кипра обмениваться информацией с налоговыми органами России. В списке Министерства Финансов РФ в настоящее время содержится 41 государство (территория) [4].

Стоит отметить, что в неопубликованном документе «Основные направления налоговой политики Российской Федерации на 2013 год и на плановый период 2014 и 2015 годов», подготовленном в рамках составления проекта федерального бюджета на очередной финансовый год и двухлетний плановый период, имеется целый абзац № 5 посвященный деофшоризации бизнеса «Противодействие уклонению от налогообложения с использованием низконалоговых юрисдикций».
Как отмечалось выше, следственно-судебная практика криминальных схем неуплаты налогов с использованием оффшорных зон, практически отсутствует. В качестве иллюстрации приведем пример американского опыта борьбы с оффшорным бизнесом, описанном в статье М. Оверченко и Р. Шлейнова «Уклонение поамерикански», опубликованной в газете «Ведомости» № 90, 27 мая 2013 года. Как отмечают авторы статьи, Подкомитет по расследованиям Сената США изучал, как именно компании избегают налогообложения в США. Результатом стало несколько докладов, которые, в частности, описывают способы, используемые Microsoft и Hewlett-Packard (опубликован в сентябре 2012 г.), а также Apple (представлен 20 мая 2012 г.). Выяснилось, что корпорации «умело» используют свои оффшорные структуры, различия между налоговыми законодательствами разных стран, а также «лазейки» в Налоговом кодексе США. У многих бизнесменов есть подконтрольные им зарубежные компании, чья прибыль во много раз превышает ВВП оффшоров. Так, в марте 2013 года The Wall Street Journal сообщила, что в 2012 г. средства 60 крупных компаний на счетах за пределами США выросли на $\$ 166$ млрд. до $\$ 1,3$ трлн. Более $40 \%$ совокупной годовой прибыли этих компаний было выведено из-под налогообложения в США. Более того, тенденция хранить деньги за рубежом наиболее заметна среди высокотехнологичных компаний и в сфере здравоохранения (по данным The Wall Street Journal обнаружила 26 таких компаний из 60 исследованных). На долю этих компаний пришлось \$120 млрд, или три четверти прироста средств на зарубежных счетах в 2012 г. У некоторых компаний на зарубежных счетах лежат почти все их деньги (так, у Johnson \& Johnson - \$14,8 млрд из \$14,9 млрд.). При этом, только 19 из 60 исследованных компаний раскрыли информацию о сумме налогов, которую они бы заплатили, если бы вернули в США всю прибыль зарубежных подразделений, - в общей сложности получилось $\$ 98$ млрд. дополнительных платежей.

Как отмечалось, основной и наиболее простой способ неуплаты налогов с использованием «оффшорных зон» - это вывод прибыли в оффшоры - трансфертное ценообразование. Трансферт активов может осуществляться несколькими способами; наиболее популярные в США, но при этом неоднозначные: лицензирование и соглашение о разделе затрат. При лицензировании юридические права на интеллектуальную собственность обычно остаются в США, зарубежным структурам передаются лишь экономические.

Транснациональные компании США используют трансфертное ценообразование, чтобы передать эко- 


\section{Системы стабилизации: финансовый контроль}

номические права на нематериальные активы подконтрольным зарубежным компаниям в налоговых гаванях, при этом расходы записываются на американские подразделения, что снижает их налогооблагаемую базу на родине. Такая практика дает транснациональным корпорациям неоправданные преимущества над местными компаниями и фактически является субсидией. Права же зачастую получают «компании-пустышки», не имеющие сотрудников, производства и нередко существующие только «на бумаге».

«Компании-пустышки» повсеместно используются американскими транснациональными корпорациями для налогового планирования, утверждает профессор Школы права Мичиганского университета Ройвен АвиЙонах. Можно утверждать, что аналогичная ситуация с «компаниями-пустышками» происходит и в России, как с применением оффшоров, так и без таковых.

Сложность в оценке нематериальных активов позволяет корпорациям искусственно завышать прибыль в низконалоговых юрисдикциях, используя агрессивные методы трансфертного ценообразования.

Проблема вывода транснациональными компаниями прибылей из-под налогообложения в США не впервые становится предметом пристального внимания властей. Так установлено, что за 2009-2011 финансовые годы Apple могла получить налоговую отсрочку, в то время как сумма пассивной прибыли ее офшорных структур была \$35,4 млрд., Google - \$24,2 млрд., Microsoft \$21 млрд.». Так же Apple удалось избежать уплаты в США \$12,5 млрд. налогов, или по \$17 млн. в день.

Еще один способ уклонения от уплаты налогов с зарубежной прибыли позволяет все-таки вернуть деньги в США. Этот способ, начиная с 2003-2004 гг, активно использует Hewlett-Packard (НР), получая краткосрочные кредиты от подконтрольных ей иностранных компаний. Обычно подобные платежи облагаются налогом, но есть ряд поправок и исключений, например, для краткосрочных кредитов, которые не переходят через квартал. Политически грамотно выстроенная стратегия борьбы с оффшорами в США, однако, дает и позитивные результаты. Так, по свидетельству «Тhе Wall Street Journal», у всемирно известной и динамично развивающейся информационно-технологической компании «Google» из 100 дочерних оффшорных компаний в 2009 г. (81 из них - на Бермудах, Нидерландских, Антильских островах и в Гонконге) к 2012 г. осталось всего две компании в Ирландии; у Microsoft в 2002 г. было больше 100 «дочек», а к 2012 г. осталось 11. Необходимо также отметить, что налог на прибыль в США составляет $35 \%$, что является одной из самых высоких ставок в мире. В России «чистая» ставка по налогу на прибыль, для сравнения, в настоящее время составляет $20 \%$.

Вообще же в России основным приемом противодействия оффшорам является составление «черного списка» подозрительных стран. Компании таких стран, как правило, дискриминируются, а резиденты, имеющие с ними дело, подвергаются определенным налоговым санкциям. На практике налоговыми органами широко используется ст. 40 НК РФ (принцип определения цены товаров, работ или услуг для целей налогообложения).

В данном случае, помимо налоговых платежей предметом неуплаты налогов могут выступать и таможенные платежи (в настоящее время понятие «таможенные налоги и сборы» изъято из НК РФ и действует понятие «таможенный платеж»). Так, к примеру, для борьбы с трансфертным ценообразованием государственные органы могут определять таможенную стоимость товара не по его контрактной стоимости, а по действующим рыночным ценам на данный товар, взятым из справочников, каталогов и т.д. Так же для предотвращения манипулирования контрактными ценами при сделках между родственными фирмами вводится «принцип вытянутой руки» - это значит, что в случае искусственного перераспределения прибыли между связанными организациями данная прибыль для целей налогообложения пересчитывается таким образом, как если бы компании были независимы (находились на расстоянии вытянутой руки). «Принцип вытянутой руки» может применяться и к торговым сделкам, роялти, процентов и т.д.

Нет сомнений в том, что если государство желает развивать местный бизнес и тем самым повышать свой экономический потенциал, оставляя большую часть денежной массы внутри страны и, соответственно, пополняя свой бюджет, необходимым ужесточить борьбу с «оффшорным бизнесом» путем конкретизации и юридического закрепления в налоговом законодательстве такого понятия как «оффшор» и ужесточить уголовноправовые меры ответственности за экономические (в том числе, налоговые) преступления с использованием оффшорных схем.

Только политическая воля в борьбе с преступным «оффшорным бизнесом» совместно с комплексным мониторингом информации в отношении российских налогоплательщиков, осуществляющих международный бизнес, с учетом обмена информацией и оперативным взаимодействием (на основании уже имеющихся совместных приказов и соглашений) между налоговыми 
DOI: $10.7256 / 1811-9018.2015 .3 .14452$

При цитировании этой статьи сноска на dоі обязательна

\section{Право и политика 3 (183) 2015}

органами, Следственным комитетом РФ, подразделениями по экономической безопасности и противодействия коррупции МВД России и НЦБ Интерпол МВД России, а так же более детальный подход при назначении наказания судебными органами России, при вынесении приговоров по фактам преступного уклонения от уплаты налогов и сборов при использовании налоговыми преступниками «офшорных схем», помогут привести к положительным результатам по «деофшоризации бизнеса» в России.

\section{Библиография:}

1. Дело ЮКОСа. Досье / Информационное агентство России [Электронный ресурc] URL: http://www.itar-tass.com/ spravochnaya-informaciya/542234 (дата доступа: 19 января 2015 г.)

2. Молчанов С.А. Налоги: расчет и оптимизация. Полный курс МВА. М.: Эксмо, 2007. 509 с.

3. Официальный сайт Министерства Финансов РФ [Электронный ресурc] URL: http://www.minfin.ru/ru/ (дата доступа: 19 января 2015 г.)

4. Перечень государств и территорий, предоставляющих льготный режим налогообложения и (или) не предусматривающих раскрытия и предоставления информации при проведении финансовых операций (оффшорные зоны), утвержденный Приказом Минфина России от 13.11.2007 № 108-н (в ред. Приказов Минфина России от 02.02.2009 № 10н, от 21.08.2012 № 115-н) [Электронный ресурс] URL: http://www.minfin.ru/ru/tax_relations/international/legislation/ (дата доступа: 19 января 2015 г.)

5. Собрание законодательства Российской Федерации. 1999. № 37. Ст. 4447.

\section{References (transliterated):}

1. Molchanov S.A. Nalogi: raschet i optimizatsiya. Polnyi kurs MVA. M.: Eksmo, 2007. 509 s. 